\title{
Influences of Teacher Preparation Program on Preservice Science Teachers' Beliefs
}

\author{
Prasart Nuangchalerm \& Veena Prachagool \\ Department of Curriculum and Instruction, Faculty of Education \\ Mahasarakham University, Mahasarakham 44000 THAILAND \\ E-mail: prasart.n@msu.ac.th
}

\begin{abstract}
Teacher preparation program is routinely make decisions regarding the best pedagogical methods from field experience studies, it can alter students' understandings about academic content and some characteristics through professional practices. This study tries to investigate the extent to which individuals learning to be teachers feel what preservice teachers are capable of performing the pedagogical practices. Sixty seven preservice science teachers were described the influences of teacher preparation. Results indicated that preservice teachers enrolled in professional experiences courses perceived themselves as less capable of performing persuasive pedagogical practices than more generally accepted practices. In addition, preservice teachers perceived they were more capable of altering students' knowledge about content than at modifying their beliefs about content. Implications for research and practice are forwarded.
\end{abstract}

Keywords: Professional experiences, Preservice teacher, Teacher preparation, Professional practice, Teaching practicum, Student teacher

\section{Introduction}

Teacher preparation and development acts as a major role in the way of growing up quality of education. The teaching professional experiences, arguably the most powerful influence in teacher education (Bullough et.al., 2002). Teacher preparation has been continually searching for the best possible ways of preparing teachers in the future. It is increasingly urged to focus on way of developing education quality through teacher preparation program. The concept of teaching professional experiences recognizes preservice teachers as key elements in their own professional growth, role of model, knowledge constructors and distributors, and agents of change in students learning behaviors (Cochran-Smith and Lytle, 1999; Darling-Hammond, 1994).

Classrooms are complex systems where many factors influence student learning (Lampert, 2002). Science teacher is an essential person in structuring and guiding students' understanding of living in the changing world. They play a role as facilitator and helper students to bridge between nature of science and inquiry practices. They also need to learn new ways of pedagogical sciences to promote scientific literacy based on inquiry-oriented classroom. In the correlation of scientific literacy, teacher preparation program need to address what they should believe about science. As responsibility of science do, preservice science teachers can help their students to meet real science by leading evidence-based and explanation-based ideas (Driver et. al., 2000; Duschl and Osborne, 2002).

The importance role of teacher preparation program is at least prepared teacher for most needy children in the most difficult circumstances (Darling-Hammond and Baratz-Snowden, 2007).

- As a society, we do not invest seriously in the lives of children, most especially poor children and children of color, who receive the least-prepared teachers.

- The conventional view of teaching is simplistic: teaching is viewed merely as proceeding through a set curriculum in a manner that transmits information from the teacher to the child.

- Many people do not understand what successful teaching requires, and do not see teaching as a difficult job that requires rigorous training.

- Others believe that there is not much more to teaching than knowing the subject matter that children should learn.

- Many state licensing systems reflect these attitudes and have entry requirements that lack demanding standards, especially for teachers who teach poor and minority students.

- Researchers and teacher educators have only recently come to consensus about what is necessary, basic knowledge for entering the classroom and how and when such knowledge and skill should be acquired.

Increasingly, the questions of teaching quality are posed regarding to the content of teacher education program, knowledge and necessary skills required, and expected tomorrow teachers (Pultorak, 1996). The framework for preservice teacher reflection based on cognitive apprenticeship, interpersonal skills, collaborative problem-solving, 
coaching and supervision, which served as a beginning for professional experiences (Campbell-Evans and Maloney, 1997; Mitchell, 1996). Real school situations where empowering preservice teachers have proven successful and provide a basis for further guidance. Teaching is perhaps only activity where preservice teachers bring with them a history of observed practice. They must be given the skills and knowledge to develop a pedagogical content knowledge, to critique practice and challenge traditional pedagogy.

As a major role of education development, the faculty of education, Mahasarakham University has been responsible for serving learning community, engage student of learning society in regional services, produce teachers and person relevant to educational services. The partially goals of us, teacher preparation program needs to have fulfillment in content, responsibility, moral, ethics, and skills. Such a conceptualization is in direct contrast with more traditional views of learning to teach (Britzman, 2003). The study aims to explore the reflection on professional experiences of preservice science teachers and what they belief about science instruction. The result of study can help educators prepare the professional experience environments, allows them learn how to be a good teacher, reflect needs of learning support in school science, and some criteria for teacher preparation.

\section{Methodology}

The 67 preservice science teacher participants in this study were enrolled in a five-year teacher education program faculty of education, Mahasarakham University. Program course work included a year-long methods course in which participants were exposed to instructional strategies, inquiry-based teaching, including models of teaching. The participants were undergraduate students in their fifth year of study enrolled course 0506509 Instructional Practice in School 1. They spent 4 months for learning what science teacher do in school. None of the participants had prior formal teaching experiences. Each preservice science teacher was required to develop and implement at least twelve-hour unit of instruction in school science. The unit of instruction consisted of a series of interconnected lessons focusing on a general topic selected by the preservice teacher and cooperating teacher. The input of the cooperating teacher and university supervisor was assessed.

In order to investigate the relationship between preservice teachers' beliefs of professional experiences program, researchers engage preservice teachers write documents and interviews. The instrument was designed to assess the preservice teacher beliefs with regard to professional experiences preparation program, school context, cooperating teacher, instructional innovation, classroom research, and supervision. When this course time out, preservice teacher come to university to clarify what are problem and need during professional experiences. The phenomenological case study design was preferred. Researchers emphasizes on inductive of data as well as subjects' belief and express ideas what preservice science teachers constructed of their own professional experiences. Also, scientific inquiry practices and belief on science were generalized. Data were collected by using qualitative questionnaires and deep listening. They discussed and sharing beliefs about what science teaching should be.

\section{Results}

Preservice science teachers reflect their own beliefs and perspectives on teacher preparation program. Most of them provided beliefs about science teaching in a various kind of school contexts. They had learned how to prepare learning scientific inquiry based on variety of methods. Also, they know and understand the entire concept that can help them to consider. However, several preservice teachers acknowledge difficulty in giving an opinion about professional experience issues due to lack of information, and some actually experiences for the school science.

\subsection{Teacher preparation program}

The concept of teacher preparation program was addressed in terms of cooperating school and university professional experiences unit. Preservice science teacher need to have clarification on their role in school, evaluation can be understandable, easy to access information on teaching practicum, and teaching fund during professional experiences.

The beliefs of preservice science teachers on teacher preparation program, they generated ideal practicum is in highly expectation. Sixteen weeks of practicum is running, they exposed many school experiences. They can be respond preparation program in terms of instructional management in such different beliefs. The findings can be explained as follows.

"I think this program should be prepared suitable instructional materials and also school and university should provide clearly criterions for coping student experiences"

"It is not surprised when I made a calling to university professional experiences unit for asking some problem that we faced in school, but staff is always busy and no less time to response"

"I believed that teaching profession is good for me, but when professional experience conducted, I am not sure it is suitable for me in the occupational future. I need more information on professional experiences and perceive clearly concept of teacher preparation program" 
It can be considered that professional experiences changes their attitude towards teaching profession, they undertake different sense in different school context. Some cooperating teachers ignore his/her role to this program, and also some of them don't care about deep listening on preservice teachers' reflection. The finding also indicate that lesson plans are very important for them to learn more and more, they love to meet cooperating teacher in way of teaching management.

Some of those preservice science teachers reflect on working behavior of cooperating teacher. They believed that mentoring can help them learn how to manipulate classroom. But, they are not quite sure that cooperating teacher believes in their own ideas and competency. However, they are ready to have suggestion on instructional strategies and accept some characteristics to be role model.

The criteria for selecting cooperating school are one thing that university should be concerned. If school had no quality and not ready to accept preservice science teachers gaining experiences in school science, university should have way to solve i.e., school should close to community, school can support money during they do professional experiences. Faculty of education and cooperating school should be informed about professional experiences plan and school details in updatable. Also, university instructor should have schedule for proposing lesson plan, it will allows time to prepare and consider the effective scientific thinking as be shown in lesson plan.

\subsection{School contexts}

The faculty of education provides preservice science teachers to have learning opportunity on teaching profession. It can be generalized that theoretical and practical pedagogy should be concurrence. Preservice teacher spent time duration at school, it can be influenced their beliefs on educational views and change their attitude towards profession. The school context is a major role that changes their view on school science. They found that some schools are facing social problem, student behaviors, instructional media and support, working place and task, and nature of school.

They raise some problem in school context, it change their belief on teaching profession in terms of theory and practice. They found that university classroom put them many learning theory and pedagogical strategies. Most theory is emerged from field study and classroom observation. Now, they are taking responsibility to do science in school, it seems to them that real classroom is very different from those university lectures.

The real school context is not frequently relevant to expectation. They expressed beliefs in terms of school change that adapt through social change. Some preservice science teachers addressed their experiences in school practicum as follows;

"School is very old and ruin, instructional materials and learning media are not sufficient and unsuitable for science classroom"

"School personnel took working task overload, and then make school atmosphere no need cooperative doing in science education"

However, preservice science teacher can be understandable that school context cannot be changed; it is large movement to do so, they think, they have to change themselves and adapt their working behavior to serve school culture. Preservice science teachers need to gain more knowledge and understanding in terms of school culture.

\subsection{Learning innovation in school science}

Preservice science teachers described their own professional experiences that professional experiences as a first chance transferred pedagogical theory into practice. Most of preservice science teacher had misconception on learning innovation; they think that material, media, and classroom facilities are innovation. They didn't think instructional model, pedagogical strategies, instructional media, and so on are innovated for school science. When we raised what learning innovation is.

Preservice science teacher raised the issue on learning activities. The 5e instructional model can be generalized in science classroom. They had too much misconception on innovated classroom. Also, demonstration method is more effective in case of poor school. School culture taught science based on IPST manual guide. The 5e instructional model is always promoted in every science hours.

"School no need change on inquiry-based teaching, teachers preferred 5e instructional model and decided to engage their students by traditional method even though education change"

Scientific knowledge is produced every day, but school didn't change method to engage their students acknowledge science. Cooperating teacher didn't learn new ways to improve science teaching, when preservice science teacher had a chance to teach science, preservice science teacher believe in their own ideas and competency. So, this finding indicated that professional development is needed.

\subsection{Education research and professional experiences}

In case of conducting educational research, preservice science teachers were assigned to do research based on science classroom in different school context. They had coopering teacher a research mentor, generate ideas to do research, and 
advise to do research are concerned. The professional practice study indicated that most cooperating teacher ignores research and also good research cannot be done.

"Cooperating teacher had no experiences of educational research, when I meet and ask for suggestion, he/she cannot be initiated research on science education or science teaching"

Most of cooperating teacher aware mostly in teaching environment than those educational researches based on their teaching class. This reason can be explained that preservice science teacher also cannot allow doing a good research in science education. It can be influenced to preservice science teachers that they don't like to do a research or think research is hard and far to reach. Not only cooperating teacher, but also attitude towards research conduction is not engaged. They indicated that educational research was exposed when they studied in the fourth year.

"I think educational research is very complex, the teacher preparation program should not assign because just only teaching and working task in classroom is overload. I need no to do a research during professional experiences"

The finding is also revealed that assignment preservice science teacher to do research is far way from their thinking. Most of them belief that no relationship between research and teaching. In this case can be decided that preservice science teacher had misconception to do educational research. Some preservice science teachers ignore and stand opposite of educational research. The faculty of education should provide them all about pedagogical technique and how to do educational research as relevant to filed of their studies. Preservice science teachers need to gain more knowledge and understanding in terms of educational research. In addition, school science might want to have doing research atmosphere to fulfillment in doing research.

Supervision is necessary for professional experiences, they need supervisor and cooperating teacher provide them how to do a good research. They need more time to discuss on teaching classroom and conducting educational research that school network and university should know and concern. However, university studying time should be incorporated research at least one research project a year. It can help student to imagine what educational research is and it cannot be separated teaching class.

\section{Discussion}

My desire is to create opportunities for students to have meaningful professional experiences with real school context after they had learned too much theory from university. The classroom culture with all its limitations remains a location of possibility for students as well as for research and teaching of preservice science teachers (Larson, 2008). Teacher preparation program need to be explained based on the differences between possibilities. Preservice teacher might want to have learned how to teach science in the age changing world. Chong and Cheah (2009) reported that preservice teachers acquire their proficiency and competence in teaching. They have inherently generic structures and the expectations of teacher performance they establish are for all classrooms in all educational contexts. But the reality of teaching can be very different. It is impossible for teacher education programs to prepare teachers for all situations. Therefore, it is important that beginning teachers are willing to learn from their experiences in changing circumstances.

The professional experiences needs to be developmental in approach, achieve on the learned skills, knowledge and attitudes towards science. The faculty of education should be aiming to develop student's responsibility for their own professional development (Nuangchalerm, 2009). The extension of the goals into professional experiences will be of benefit in the future. The studies led to initial observations that preservice science teacher have to practicum in one year school science. The coaching and supervision are important things that provide positive encouragement to the idea of reflective practice during teaching practice. The professional experiences reflect practice through mentor and supervision, school discussion based on problem-solving in different contexts can promote interpersonal quotient (Pence and Macgillivray, 2008).

Helping preservice teachers' understand the rationale behind why a particular inquiry-based practice is important in science may result in students being better able to complete a performance. Crawford and others (2000) argues that one of the key characteristics of a teacher establishing an inquiry-based learning environment. It can help students learn new things through inquiring mind and seems to scientists do. This will help students understand that the ways of talking and thinking in science is different from those in students' everyday experiences.

In case of conducting educational research through teacher preparation program, the findings pointed that most of preservice science teachers need to fulfill concept and practical guide about educational research. It seems to preservice teachers that they need to provide explicit instruction and research. Also, they need to learn the differences between students' everyday discourses and scientific discourses based-on research methodology (Lee, 2004). The faculty of education should structure teacher development by promoting research-based teaching into education course based on possibility and reflect their ideas in science teaching and of science education research.

\section{References}

Britzman, D.P. (2003). Practice makes Practice: A Critical Study of Learning to Teach. New York: State University of New York Press. 
Bullough, R.V.,Jr., Young, J., Erickson, L., Birrell, J.R., Clark, D.C. and Egan, M.W. (2002). Rethinking Field Experiences: Partnership Teaching versus Single-placement Teaching. Journal of Teacher Education. 53 (1): 68-80.

Crawford, T, Kelly, G., and Brown, C. (2000). Ways of Knowing beyond Facts and Laws of Science: An Ethnographic Investigation of Student Engagement in Scientific Practices. Journal of Research in Science Teaching. 37(3): 237-258.

Campbell-Evans, G. and Maloney, C. (1997). An Alternative Practicum Curriculum: Exploring Roles and Relationships. Asia-Pacific Journal of Teacher Education. 25 (1): 35-52.

Chong, S. and Cheah, H.M. (2009). A Values, Skills and Knowledge Framework for Initial Teacher Preparation Programmes. Australian Journal of Teacher Education. 34(3):1-17.

Cochran-Smith, M. and Lytle, S.L. (1999). The Teacher Research Movement: A Decade Later. Educational Researcher. 28 (7): 15-25.

Darling-Hammond, L. (Ed.). (1994). Professional Development Schools: Schools for Developing a Profession. New York: Teachers College Press.

Darling-Hammond, L. and Baratz-Snowden, J. (2007). A Good Teacher in Every Classroom: Preparing the Highly Qualified Teachers Our Children Deserve. Educational Horizons. 111-132.

Duschl, R. A. and Osborne, J. (2002). Supporting and Promoting Argumentation Discourse in Science Education. Studies in Science Education. 38: 39-72.

Lampert, M. (2002). Appreciating the Complexity of Teaching and Learning in School: A Commentary on Cobb; Froman and Ansell; McClain; Saxe; Schliemann; and Sfard. The Journal of the Learning Sciences. 11 (2\&3): 365-368.

Larson, M.L. (2008). Preservice Literacy Teachers in Transition: Identity as Subjectivity. The International Journal of Learning. 15 (6): 203-210.

Lee, O. (2004). Teacher Change in Beliefs and Practices in Science and Literacy Instruction with English Language Learners. Journal of Research in Science Teaching, 41(1), 65-93.

Mitchell, J. (1996). Developing Reflective Teaching: Negotiation in the Practicum. Asia-Pacific Journal of Teacher Education. 24 (1): 47-61.

Nuangchalerm, P. (2009). Implementing Professional Experiences to prepare Preservice Science Teachers. The Social Sciences. 4(4): 388-391.

Pence, H.M. and Macgillivray, I.K. (2008). The Impact of an International Field Experience on Preservice Teachers. Teaching and Teacher Education. 24: 14-25.

Pultorak, E. (1996). Following the Developmental Process of Reflection in Novice Teachers: Three Years of Investigation. Journal of Teacher Education. 44 (4): 288-295. 